\title{
Norwegian General Hospitals, 1970-2002: County Ownership_An Interlude between Welfare Localism and State Direction
}

\author{
TORE GRØNLIE*
}

Over the last three decades, Norway has experienced two fundamental reforms in hospital organization and direction. In 1970 the nineteen county authorities took over ownership and budget responsibilities for hospitals within their areas, replacing a highly varied and complex structure of ownership, typically generated locally. In 2002 hospitals were transferred to the state and amalgamated into five regional government enterprises. These, in turn, have organized all hospitals in their region under local health enterprises. Both regional and local enterprises are separate legal entities, with their own executive boards and managing directors. The Minister of Health appoints the boards of the regional enterprises, while their directors and the boards of the local enterprises are appointed by the regional boards. Both regional and local enterprises are supposed to have full autonomy for day-to-day operations, while being subject to strategic and political decisions by the Minister of Health as the ultimate authority of the enterprise assembly (foretaksm $\phi t e) .{ }^{1}$ The "enterprise" concept is, of course, borrowed from private business, modelled on companies of limited liability. The choice of this organizational model must be understood at least partly within the context of a general politico-administrative reform, inspired by the worldwide New Public Management movement. Each enterprise is a separate economic entity with a clear responsibility for balancing its budgets. Privatization (or part-privatization) and bankruptcy, however, are out of the question, as the state in the end retains full economic responsibility.

The objective of this article is to contribute towards an understanding of this pattern of reform. I will suggest three explanations. First, ownership and organization in the hospital sector falls nicely into a long line of development in the creation of the Norwegian welfare state-with the emphasis on "state". This can be described as the development from "welfare localism" to central direction with the aim of equalizing welfare provisions

\section{(C) Tore Grønlie 2006}

Professor, dr. philos. Tore Grønlie, Department of History and the Stein Rokkan Centre for Social Studies, University of Bergen, Nygårdsgaten 5, 5015 Bergen, Norway, e-mail: tore.gronlie@hi.uib.no.

This article should be considered more of a framework for research at an early stage in a research project on the Norwegian hospital organization and direction since 1970 , than a report on the results of research. I am greatly indebted to several historians and political scientists who have earlier contributed to the field, as notes will show. I am also grateful for most constructive comments by the referees.
What are considered here are general somatic hospitals, not psychiatric institutionalized care or specialized institutions. In general, the state, at an early time, took greater responsibility for the building and running of psychiatric and specialized institutions, than for general somatic hospitals.

\footnotetext{
${ }^{1}$ Drawing the dividing line between what are strategic or political questions on the one hand and day-to-day operations on the other, is a central and most difficult task in this form of public enterprise, as in all others. In the course of the four years of implementation of the reform the problem has already caused several conflicts and heavy media exposure. In the wider setting of general Norwegian public administration
} 


\section{Tore Grønlie}

nationally. The desire to secure equal rights, care and benefits nationwide has always been a concern of the state, but I will argue that this concern has greatly increased over the last few decades. From this perspective, the two reforms in 1970 and 2002 could even be considered as two steps in one and the same process. This theme of centralization versus decentralization is, of course, a general and common one in international hospital history, ${ }^{2}$ and in the on-going reform debate on hospital organization in several countries in the western world. It is also an important theme in ongoing social science research on current hospital reform. A central question in this respect, which calls for a broader comparative approach than is possible within the scope of this article, is whether developments in Norway - from a decentralized towards a centralized system of hospital organization-run counter to a general trend towards decentralization of hospital management and direction, and if this is the case, why? ${ }^{3}$

Secondly, both the reorganization of the 1970s and that of 2002 fall neatly into a broader picture of fundamental Norwegian political and administrative government reform. Important factors behind both hospital reforms are thus at least as much connected to the problems of reorganization of government and administration in general, as they are specific to hospital politics. Thirdly, the fundamental problems and tensions that inspired reform at the beginning of the new millennium were basically the same as those that made reform necessary thirty years earlier. Several problems in hospital politics were probably greater at the end of the three decades of county ownership than at the beginning. I will therefore argue that it is possible to see the phase of general county ownership as an interlude in a hundred-year-long search for the "right" way of organizing Norwegian hospitals. Circumstances and what are considered good and appropriate organizational solutions probably change more than the fundamental problems of hospital politics, which have turned out to be surprisingly consistent and recalcitrant. State regional enterprise is just as much the hegemonic politico-administrative "solution of today" as county ownership was in the 1960s and 1970s.

\section{Health Care Traditions, Organization and Politics in Norway}

The Norwegian health care system has been characterized as belonging to a Nordic family of decentralized systems heavily dependent on public funding, in contrast to an

policy, this theme is discussed in Tore Grønlie, 'Drømmen om en konkurransetilpasset stat -Ytre fristilling som styringspolitisk redskap -1945-1965', in Tore Grønlie and Per Selle (eds), Ein stat? Fristillingas fire ansikt, Oslo, Det Norske Samlaget, 1998, pp. 66-106; Tore Grønlie, 'Mellom politikk og marked - organisering av statlig næringsdrift', in Bent Sofus Tranøy and Øyvind Østerud (eds), Den fragmenterte staten: reformer, makt og styring, Oslo, Gyldendal, 2001, pp. 301-32; Per Lægreid, Ståle Opedal and Inger Marie Stigen, 'The Norwegian hospital reform - balancing political control and enterprise autonomy', Paper to the 17th Nordic Conference on Business Studies, Reykjavik, 14-16 August 2003, Rokkansenteret, Working Paper 23, 2003; and Tom Christensen, Per Lægreid and Inger
Marie Stigen, 'Performance management and public sector reform: the Norwegian hospital reform', Paper to the EGPA conference, Ljubljana, 1-4 September 2004.

${ }^{2}$ For the British case, see John Mohan, Planning, markets and hospitals, London, New York, Routledge, 2002.

${ }^{3}$ The question raised is central to the research project 'Autonomy, transparency and management, three reform programs in health care: a comparative project' at Rokkansenterert (Stein Rokkan Centre for Social Research), University of Bergen, see Haldor Byrkjeflot, 'The making of the health care state? An analysis of the recent hospital reform in Norway' (Paper to the Bergen Workshop on the History of Health and Medicine, 18-19 March 2004), in Astri Andresen, Tore Grønlie and Svein Atle Skålevåg (eds), Hospitals, 


\section{Norwegian General Hospitals, 1970-2002: County Ownership}

American system with corporate actors involved in both funding and provision of health care, the post-1948 UK centralized National Health Service model, and the continental social insurance models. ${ }^{4}$ Funding for the running of hospitals is raised almost exclusively by taxation, although a major part of it is channelled through a system of national health "insurance", introduced on a decentralized basis before the Second World War, made compulsory, universal and incorporated into a fully integrated state system of health benefits and pension schemes before the end of the 1960s. Within the dominant public sphere, the state, traditionally, has filled important functions in funding and in regulatory regimes. Ownership and the running of hospitals, however, has as a rule been a domain of the local and county government, more often than not subject to the general local or county self-governing representative authorities.

There are important similarities between the Norwegian pre-1970 and the UK pre-1948 systems, in so far as both were heavily decentralized and built upon a mixture of private (voluntary) and public ownership and finance, and local and county authorities were the central players on the public side. There is, however, one basic difference: while in the British system, the voluntary sector was much greater than the municipal one, and the strong municipal hospital efforts in the period between the world wars could be seen in the light of easing the shortcomings of the voluntary sector, ${ }^{5}$ the voluntary sector of Norway was considerably less important, its position being more that of a supplement to the dominant public one.

The politico-administrative system of Norway builds upon a three-level structure, the state, a middle structure consisting of nineteen counties (fylker) of varying size (half of them having between 150,000 and 250,000 inhabitants), and 435 (before the mid-1960s 744) local authorities (kommuner) of which almost 60 per cent still have less than 5000 inhabitants. Until 1964 county authorities had jurisdiction only over the rural areas of their county; towns and cities stood outside. The county authorities — until the mid-1970s—were composed of the mayors of the rural member communities.

patients and medicine, Conference Proceedings, Rokkansenteret, Report 6, Bergen, Stein Rokkan Centre for Social Studies, 2004, pp. 55-76; Haldor Byrkjeflot and Simon Neby, 'Norge i Norden: Fra etternøler til pioner i reformering av sykehussektoren', in Ståle Opedal and Inger Marie Stigen (eds), HelseNorge i stфpeskjeen: søkelys pa sykehusreformen, Bergen, Fagbokforlaget, 2005, pp. 47-61. For international comparison, see, for example, Richard Freeman, The politics of health in Europe, Manchester University Press, 2000; Richard B Saltman, 'Convergence versus social embeddedness: debating the future direction of health care systems', Eur. J. Public Health, 1997, 7 (4): 449-53; Richard Freeman and Michael Moran, 'Reforming Health Care in Europe', in M Ferrera and M Rhodes (eds), Recasting European welfare states, London, Frank Cass, 2000, pp. 35-58.

${ }^{4}$ Freeman, op. cit., note 3 above, pp. 5-7; Simo Kokko, Petr Hava, Vicente Ortun and Kommo Leppo, 'The role of the state in health care reform', in Richard B Saltman, Joseph Figueras and Constantino
Sakellarides (eds), Critical challenges for health care reform in Europe, Buckingham, Open University Press, 1998, pp. 289-307. There is no space here to go into nuances and historical developments and change. Models like these in general exaggerate differences between health care systems and downplay historical change. Freeman himself warns against relying too much on rigid classifications, as all health systems are mixtures of different principles of organization and finance (pp. 6-7). Moreover, tensions and conflicts of a general nature of the type focused on in this article are found in all countries, whatever the systems. Models are put forward here mainly as a point of departure for a more qualified, empirically based analysis of the development of the Norwegian hospital system.

${ }^{5}$ John Mohan, 'Voluntarism, municipalism and welfare: the geography of hospital utilisation in England in 1938', Trans. Inst. Br. Geogr., 2003, 28 (1): 56-74; Martin Gorsky, John Mohan and Martin Powell, 'British voluntary hospitals, 1871-1938: the geography of provision and utilisation', J. Hist. Geog., 1999, 25 (4): 463-82; Mohan, op. cit., note 2 above, pp. 21-67. 


\section{Tore Grфnlie}

The political scene in Norway between 1935 and 1980 was heavily dominated by the Labour Party (Social Democrat), governing from a majority position in Parliament between 1945 and 1965. Since 1980 power has constantly shifted between Social Democratic and Conservative or Conservative-centre coalitions, as a rule, however, now in minority positions. During most of the post-Second World War period the building and upkeep of a generous and universal welfare state and an ambitious national equalization policy has been a widely shared goal among most Norwegian political parties. Since the late 1970s, however, under the combined pressures of greater economic austerity and international movements for the "modernization" and scaling down of the public sector, political splits have emerged, typically over the issues of limiting the scope and generosity of some welfare provisions, the introduction of user contributions and the strengthening of the (highly limited) private components of the health care system. The relative wealth of the Norwegian state as a result of North Sea oil revenues, however, has contributed greatly towards making the need for reducing expenditure on public health care less pronounced than in most countries.

\section{Before the Second World War: Welfare Localism-Cities and Towns in the Lead}

The breakthrough in broad-scale hospital expansion in Norway followed urbanization towards the end of the nineteenth century. ${ }^{6}$ Growth was strongly characterized by what could be called "welfare localism": hospital building to satisfy locally felt needs for hospital care. In Norway, the expression "welfare municipality" (velferdskommunen) is often used as a label for communities that were especially active in the early initiation of welfare provisions in general, emphasizing the prominent role of local self-governing authorities. ${ }^{7}$ The term "welfare triangle" has been used to denote the important tripartite partnership between local authorities, private humanitarian organizations, and the state in the building of the welfare state. ${ }^{8}$ I would argue that welfare localism fits our casehospitals - better. It covers a broad and highly varied spectrum of local interests taking part in the expansion of the hospital sector over more than three-quarters of a century. Involved parties included local and county authorities, humanitarian organizations, private donors, spontaneously created hospital associations and even companies, which in some cases were required to participate by state concessionary statutes. ${ }^{9}$ The state contributed substantially: through investment, by contributions to running expenses (after 1909 mainly from national

\footnotetext{
${ }^{6}$ See, for example, Rolf Danielsen, 'Kommunaliseringsprosessen i norske byer 1880-1920', in Anne-Hilde Nagel (ed.), Velferdskommunen: kommunenes rolle i utviklingen av velferdsstaten, Bergen, Alma Mater, 1991, pp. 53-60.

${ }^{7}$ Tore Grønlie, 'Velferdskommunen', in Nagel (ed.), op. cit., note 6 above, pp. 43-52; Edgar Hovland, 'Grotid og glanstid. 1837-1920', in Hans Eyvind Næss, Edgar Hovland, Tore Grønlie, Harald Baldersheim and Rolf Danielsen, Folkestyre $i$ by og bygd: norske kommuner gjennom 150 ar, Oslo, Bergen, Stavanger, Troms $\varnothing$, Universitetsforlaget, 1987, pp. 127-43;

Tore Grønlie, 'Velferdskommune og utjevningsstat,
}

1945-1970', in Næss, Hovland, Grønlie, Baldersheim and Danielsen, ibid., pp. 251-78.

${ }^{8}$ Anne-Lise Seip, 'Velferdskommuen og velferdstrekanten - et tilbakeblikk, in Nagel (ed.), op. cit., note 6 above, pp. 24-42.

${ }^{9}$ Aina Schiøtz, Folkets helse - landets styrke 18502003, series: Det offentlige helsevesen i Norge 16032003, vol. 2, Oslo, Universitetsforlaget, 2003, pp. 320, 322-24; Aage Engesæter and Johs B Thue, Sogn og Fjordane fylkeskommune gjennom 150 air, Oslo, Det Norske Samlaget, 1988, pp. 217-24; Finn Henry Hansen, 'Sykehusstruktur i historisk perspektiv', in Finn Henry Hansen (ed), Sykehusstruktur 


\section{Norwegian General Hospitals, 1970-2002: County Ownership}

health "insurance", mandated by law, to which the state from the beginning contributed 20 per cent ${ }^{10}$ ), and through the building of hospitals for special purposes or national specialized care. Initiatives in hospital expansion, however, were more often than not local. Quite simply, for several decades, hospital development in Norway as a whole could best be understood as a nationwide "chipping in" (spleiselag or dugnad). One scholar has characterized the localization and expansion of hospitals as "almost anarchic". ${ }^{11}$ This development, in its turn, could be considered in the wider context of a "Norwegian system" of expanding collective services, through activating and bringing together resources from wherever they could be found. ${ }^{12}$ In 1930, 21 per cent of beds in general hospitals in Norway were in private institutions, 8 per cent were state owned, while 71 per cent were owned by local authorities (51 per cent), county authorities (11 per cent), or had joint local and county public ownership ( 9 per cent). ${ }^{13}$

One type of actor, in particular, stands out in the collaborative effort- the cities and larger towns. The most important role in hospital building and expansion was played by municipal authorities. ${ }^{14}$ It is important to bear in mind the great economic — and culturaldifferences between town and countryside, especially between the cities of some size and peripheral rural communities. The towns and cities, at least periodically, had a basis of relative wealth, a surplus to use for welfare expansion for their inhabitants that the rural communities normally could not muster. And, of course, only the cities and towns had a population base that was big enough for health institutions of a notable size.

As the figures show, however, county authorities also played a substantial part in hospital expansion. ${ }^{15}$ But it is important to note that the county authorities of the time normally did not have economic resources that were at all comparable to those of the bigger cities and towns. At the same time, it can be argued that cities and towns tended to view hospitals, and social and cultural institutions, not only as an obligation, but also as status symbols (adelsmerke) or privileges. Hospitals and cultural institutions

i endring: de langer linje og utviklingen siste tiair, Samdata sykehus report 3/01, Trondheim, SINTEF Unimed, NIS SAMDATA, 2001, pp. 35-63. The localized origin of hospitals is underlined also in the British case, see Mohan, op. cit., note 2 above, pp. 1-20.

${ }^{10}$ Hovland, op. cit., note 7 above, pp. 131-2.

${ }^{11}$ Hansen, op. cit., note 9 above, p. 38: "nærmest "anarkisk",

${ }^{12}$ Jens Arup Seip, Tanke og handling $i$ norsk historie, Oslo, Gyldendal, 1968, pp. 22-71.

${ }^{13}$ NOS IX.2, Sunndhetstilstanden og medisinalforholdene 1930, Det Statistiske Centralbyrå, Oslo, 1933. The pattern of institutionalization, the institutional profile of different actors and owners, and variations over time and across regions has so far not been subjected to historical analysis in any detail. A project focusing on these problems is under way at the Rokkansenteret (Stein Rokkan Centre for Social Research), University of Bergen. Basic statistics and listings of institutions by ownership and geography in both 1960 and 1964 are given in 'Innstilling om sykehusordningen', Innstilling II fra komiteen til utredning av sykehusordningen
(Sykehusordningskomiteen), 1963, Appendix 2, parliamentary documents (Norway), Ot.prp. nr. 36 (1967-68), 'Om lov om sykehus' (On law on hospitals).

${ }^{14}$ See, for example, Hansen, op. cit., note 9 above, pp. 36-8. Accounts of inter-war municipal hospital expansion in Britain are given in John V Pickstone, Medicine and industrial society, Manchester University Press, 1986; Roger Lee, 'Uneven zenith: towards a geography of the high period of municipal medicine in England and Wales', J. Hist. Geog., 1998, 14 (3): 260-80; Mohan, op. cit., note 5 above, pp. 56-73; and Mohan, op. cit., note 2 above, pp. 21-44.

${ }^{15}$ See, for example, Schiøtz, op. cit., note 9 above, pp. 320, 322-7; Engesæter and Thue, op. cit., note 9 above, pp. 217-24; Tor Selstad, Trøndelags romlige utvikling. Historier og scenarier 1030-2030, Rapport nr. 2 fra Trøndelagsprosjektet, Trondheim, NTNU, Geografisk institutt, 2002; and Astri Andresen, 'Sykehuset - fra utkanten av helsevesenet til sentrum', in Marit A Hauan, Einar Niemi, Helge A Wold and KetilZachariassen (eds), Karls $\phi$ y og verden utenfor. Kulturhistoriske perspektiver pa nordnorske steder, Troms $\emptyset$ Museum, Universitetsmuseet, 2003, pp. 232-49. 


\section{Tore Grфnlie}

constituted a major contribution towards the making of a town. Towns without these kinds of institutions were of a lower order and this realization probably spurred them on to raise their status. At the same time, having a hospital implied an obligation to extend hospital care to the population of surrounding rural communities and smaller towns. The larger towns contributed to others "out of their riches" while primarily paying for better health care for their own inhabitants. For example, until 1952, the city of Bergen alone covered the investments and deficits of the city hospitals (mainly Haukeland Sykehus), even though one-fourth to one-third of the patients during the first decade after the war came from communities outside the city borders. ${ }^{16}$ It is not yet known how representative this was.

The will to engage in building costly welfare institutions was, in general, considerably less evident at the county level than at that of cities and towns, as were the resources available for such ventures. The county authority was primarily an institution of support for the rural communities of the county. It was, as already stated, composed of the mayors of the member communities; it depended on taxes levied indirectly on the local communities and it tended to concentrate on basic and not too costly services for the rural population. Representatives of member communities generally wanted to keep costs down out of concern for the tax burden in their home constituencies. Different parts of geographically diverse counties had conflicting interests as to the location of county hospitals. The bigger and more well-to-do communities of the county-often densely populated areas bordering on a hospital town or city-had no great interest in paying for services or care that primarily catered for the less fortunate of the periphery. ${ }^{17}$ An example will illustrate this. The county of Hordaland, surrounding the city of Bergen, had since the early 1920s owned a building lot intended to be the site of a county hospital, but this was never built. The county authorities relied on small private or local authority hospitals in some of the smaller towns, and on sending patients to Bergen. Only after 1952 did the county pay for the deficit generated by its own patients. ${ }^{18}$

County authorities were generally more active hospital entrepreneurs in counties without towns or cities of some wealth or without relatively easy access to such urban centres. This was typically so in northern Norway and the counties of Northern Trøndelag and Sogn og Fjordane. ${ }^{19}$ In some cases, however, even county authority hospitals were located in or close to the bigger cities or towns. ${ }^{20}$ In other counties, intra-county conflicts of interest and tight county economies contributed towards stimulating localism and the building of

\footnotetext{
${ }^{16}$ Tore Grønlie, '1945-1972', in Anders-Bjarne Fossen and Tore Grønlie, Byen sprenger grensene 1920-1972, vol. 4 of Bergen bys historie, Bergen, Universitetsforlaget, 1985, pp. 788-98. The running of hospitals was paid for by national health insurance (collected through taxation) on the basis of rates supposed to be sufficient to cover care on a day-to-day basis. Before the Second World War rates were set unilaterally by the hospital owner. During and after the war rates were set by the State Directorate of price controls, generally at a level considerably below the actual costs. The hospital owner had to cover the deficits. In 1980 a system of block grants was introduced. After 1997 a percentage of block grants
}

(thirty initially, growing to sixty over the years) were made dependent on hospital activity.

${ }^{17}$ The same kind of split between cities and towns on the one side and counties on the other, was found in the pre-NHS system in Britain, see Mohan, op. cit., note 2 above, pp. 21-67.

${ }^{18}$ Grønlie, op. cit., note 16 above, pp. 788-98; Karl Egil Johansen, Pa sjølvstyr gjennom 150 air. Hordaland fylkeskommune 1837-1987, Bergen, J W Eide, 1987, pp. 164-70.

${ }^{19}$ Engesæter and Thue, op. cit., note 9 above, pp. 217-24; Selstad, op. cit., note 15 above, pp. 27-8; Andresen, op. cit., note 15 above, pp. 232-49.

${ }^{20}$ See Andresen, op. cit., note 15 above, pp. 232-49. 
scattered small hospitals instead of one or a few bigger ones. ${ }^{21}$ Thus emerged a structure combining relatively few big city hospitals and a host of small ones for local care.

The 1940s, 1950s and 1960s:

\section{Towns, Counties or the State-Whose Responsibility?}

All of this gradually changed. The economic problems of the 1920s and early 1930s brought the cost of welfare provision into focus, and hospitals were of prime importance. The financially less tight late-1930s and early post-war period eased the heaviest strains, but did not relieve cities and towns of their financial concerns. Aspirations and costs of hospital care grew. In active welfare municipalities, hospitals increasingly encountered competition for resources from a host of other welfare schemes and programmes, pensions initiated and paid for locally, a broad array of social institutions and an ambitious expansion in education. The prestige of being the provider of hospital care was lost in the face of hard economic realities, and, for the first time, a forward looking state hospital policy was initiated. All interested parties searched for new solutions. Cities and towns were no longer interested in accepting "free riders" from surrounding communities and looked for help to carry increasing costs. Rural districts, represented by the county authorities, were often in acute need of better health care for their inhabitants, but generally looked for the cheapest possible alternative. The state sought ways to organize a very necessary expansion, a general improvement in the quality of hospital care, coordination and specialization on the regional and national levels, and the lessening of differences in hospital services between local communities, counties and regions. ${ }^{22}$

For some time no clear alternative materialized. In the early 1930 s, state medical authorities had initiated a national plan for hospital development-built on information from county authorities - as part of a budding national health policy. ${ }^{23}$ Shortly after the war, in 1948, county-based plans for hospital development were produced, and the decision was taken to establish "central hospitals" (sentralsykehus) as the fundamental unit in a hierarchy of hospitals, with the county as its population base. ${ }^{24}$ A systematic county-based organization and direction, however, did not materialize for more than twenty years. The county was still, and remained for a long time, very far from an ideal home for hospitals. As a well-defined geographical unit, and the only (official) one between the local municipalities and the country at large, the county could easily be considered as the natural unit for hospital planning, and several had some or considerable experience as hospital owners. But at the same time, as previously indicated, the county was not a unitary political and administrative entity ready to encompass a system of organization and direction designed

\footnotetext{
${ }^{21}$ Engesæter and Thue, op. cit., note 9 above, pp. 217-24.

${ }^{22}$ Schiøtz, op. cit., note 9 above, pp. 318-26; Grønlie, op. cit., note 16 above, pp. 788-98; Johansen, op. cit., note 18 above, pp. 164-70. There are striking similarities between the organizational shortcomings of the Norwegian hospital system and the lack of integration or coordination in the UK system before the establishment of the NHS in 1948, and between the
}

political debates in the two countries, for example, Charles Webster, The National Health Service: a political history, Oxford University Press, 2002, pp. 3-7; Mohan, op. cit., note 2 above, pp. 21-67; Pickstone, op. cit., note 14, pp. 251-95.

${ }^{23}$ Schiøtz, op. cit., note 9 above, p. 319; Hansen, op. cit., note 9 , pp. $38-41$.

${ }^{24}$ Schiøtz, op. cit., note 9 above, p. 321; Hansen, op. cit. note 9 , pp. 41-4. 


\section{Tore Grønlie}

to govern the complete hospital system of its area. The county was split between institutions for self-government and state functions, and, more importantly, cities and towns-so dominant in hospital ownership_-stood outside the self-governing, service-generating, institutions of the county.

The county that could become a home for hospital organization and direction in general, simply did not exist. In the 1940s and 1950s, state efforts to reform local and regional government and administration were channelled into reorganizing the structure of local communities, amalgamating towns and rural communities into bigger and economically more robust units. Well into the 1960 s there was also considerable political resistance to the ideas of reorganizing the county authorities into politico-administrative units capable of handling important and expanding welfare sectors-such as hospitals and secondary education. $^{25}$

For all these reasons, the collaborative (spleiselag) model for organizing hospital care was continued, although with the county authorities in an increasingly prominent position. ${ }^{26}$ There was a clear tendency towards county takeover from local authorities and private owners that experienced mounting financial difficulties; ${ }^{27}$ and there was also a strong propensity towards organizing cost-sharing partnerships, not only for the expansion of hospitals or the building of new ones, but for the costs of providing care as well. ${ }^{28}$ Different models were tried out: partnerships between all the local authorities (city and rural) within a county, and co-ownerships or amalgamations between county and city hospitals. ${ }^{29}$ Between 1946 and 1963 the share of hospital beds owned jointly by local authorities and counties grew from 7 to 27 per cent. ${ }^{30}$ Bergen-Hordaland even provides an example of a tripartite partnership: in 1956 the city-owned hospital was reorganized as a "hospital partnership", in which the city of Bergen, the county of Hordaland, and the state participated. The main principle of cost sharing was that Bergen and Hordaland would carry the deficits for patients living within their borders. The state would pay the deficit for those patients from outside Bergen and Hordaland, and also a part of that for patients considered to be cases of national concern. Extremely difficult choices and conflicts, with ensuing negotiations, arose from the fact that one and the same hospital was supposed to have the different functions of local hospital for Bergen, central hospital for Hordaland, and regional hospital for all the counties in western Norway. To make matters even more complicated, after Bergen became the home of the second university of Norway in 1946,

\footnotetext{
${ }^{25}$ Y Flo, Mellom stat og sjølvstyre: fylket i norsk styringsverk etter 1945, LOS-senter Report 0003, Bergen, LOS-senter, 2000, pp. 24-34.

${ }^{26}$ It has been suggested that counties gradually took on an "unwritten responsibility" (det uskrevne ansvar) for hospital development, see Kari Martinsen, 'Helsepolitiske problemer og helsepolitisk tenkning bak sykehusloven av 1969', Historisk Tidsskrift, 1987, 3: 357-72, p. 366. Finn Henry Hansen similarly talks of an "anticipation" of a future county model of hospital ownership, Hansen, op. cit., note 9 above, p. 45.

${ }^{27}$ Johansen, op. cit. note 18 above, p. 169; Engesæter and Thue, op. cit., note 9, pp. 296-307.

${ }^{28}$ Partnerships were used for managing conflicts of interests between cities, towns and counties in
}

pre-NHS Britain also, but developed to highly varying degrees, see Mohan, op. cit., note 2 above, pp. 45-67, esp. pp. 50-1. See also Pickstone, op. cit., note 14 above, pp. 272-95; and Martin Gorsky, "Threshold of a new era": the development of an integrated hospital system in northeast Scotland, 1900-39', Soc. Hist. Med., 2004, 17 (2): 247-67.

${ }^{29}$ An overview of hospital cooperation and partnerships is given in 'Innstilling om sykehusordningen', appendix 22, note 13 above.

${ }^{30}$ Hansen, op. cit., note 9 above, p. 46. 


\section{Norwegian General Hospitals, 1970-2002: County Ownership}

the state, as the owner of the university, was supposed to cover investments in both buildings and equipment and the running costs of the new faculty of medicine and the hospital's functions as a university clinic. The result was a more or less constant tug-of-war between the parties involved that lasted until the county took over ownership in 1972. In the meantime, however, the state increasingly carried the financial burden. The conflicts caused a long line of aggravating postponements of the construction of the new regional hospital and university clinic in Bergen. ${ }^{31}$

A uniform organizational model for hospital ownership and direction was, therefore, not created until 1969, with the passing of the first general hospital law in Norway. ${ }^{32}$ The lack of a realistic mid-level alternative to town or state ownership, is, in all probability, the main reason for this. The age of the city- or town-owned hospital was gone. State ownership had few adherents at the time, but it also seems reasonable to claim that for a long period hospitals were given lower priority in state welfare policies than some other welfare programmes, notably the development of state pension schemes, which were considered by many the backbone of the welfare state. In general, welfare also took second place to the strengthening of economic growth: first and foremost post-war reconstruction and industrialization. $^{33}$

\section{The 1969 Hospital Law and The "Hospital County"}

In the 1960s and 1970s, however, Norway witnessed a total transformation of the county level of governance and, as a parallel and integrated process, the creation of the first unitary system of hospital organization throughout the country. This happened through several simultaneous processes and initiatives for change. First, the reorganization of the county level of governance could be considered the natural second step in the fundamental reorganization of local and regional government. The previous one had consisted of amalgamations and strengthening of the local authorities in the 1950s and first half of the 1960s. In the course of three decades, the local and county systems of government were remoulded to become the prime tool for the national government in developing the welfare state. Second, the new county authorities were created in response to two other forceful impulses of the late 1960s and early 1970s: an ideologically based process of democratization of considerable strength, paralleled by a strong anti-bureaucratic sentiment. Over little more than a decade, county governance was completely changed: cities and towns were included from 1964, then came the separation of state and county functions, elections to the county authorities by popular vote, direct county taxation and the creation of an autonomous county administration, all completed by 1976. Paralleling the inclusion of towns and cities in the new county, the state recommended county take-over of hospitals (and secondary schooling) from 1964. Accordingly, between 1963 and 1970, county ownership grew from 20 to 63 per cent of hospital beds, while joint ownerships between local

${ }^{31}$ Grønlie, op. cit., note 16 above, pp. 788-98; Johansen, op. cit., note 18 above, pp. 164-70; Astrid Forland, 'Universitetet i Bergens historie 1946-1996', in Astrid Forland and Anders Haaland, Universitetet $i$ Bergens historie, 2 vols, University of Bergen, 1996, vol. 1, pp. 350-9.

\footnotetext{
${ }^{32}$ For a review of the general contents of this law and the processes leading up to it, see Martinsen, op. cit., note 26 above, pp. 357-72.

${ }^{33}$ Trond Nordby, Karl Evang: en biografi, Oslo, Aschehoug, 1989, pp. 171-92, 215-18, on p. 218; Martinsen, op. cit., note 26 above, p. 358.
} 


\section{Tore Grønlie}

authorities and counties all but disappeared. Beds in private institutions fell to 8 per cent. ${ }^{34}$ The 1969 hospital law made county ownership the general rule. Hospitals under private ownership were allowed to continue in private hands, and granted public funding, but this depended on their integration into county authority hospital planning and division of labour. ${ }^{35}$ Hospital reorganization fitted extremely well into the politico-administrative paradigm of the day: county-based organization, a strong belief in democratic processes and the popular vote, anti-bureaucracy, an almost extreme optimism regarding planning and coordination under the direction of representative political institutions, and a correspondingly optimistic attitude towards an almost unlimited expansion of the welfare state. ${ }^{36}$

At the same time county ownership was supposed to counteract localism. The new county authority and hospital reorganization were created, therefore, through an almost symbiotic relationship. City and town membership of the county was a necessary prerequisite for county hospital organization, and the costly hospital functions in the hands of the county, in turn, made necessary or natural the subsequent democratic, financial and administrative reorganization of county authorities. ${ }^{37}$ It is also noteworthy that the model of the new county authority during the 1960s and 1970s defeated two competing models for administrative reorganization; one built on the expansion of state administrative agencies, a model that was very strong in the 1950s and 1960s, and another on ideas of regional (landsdels) planning. ${ }^{38}$ It is not yet known whether there were important influences from abroad. The 1970s were, however, a decade of democratization and decentralization internationally. Sweden already had a long and well-established tradition of county ownership of hospitals, and Denmark, in a process parallel to that of Norway, adopted comparable systems.

\section{Transfer to the Counties: Few Problems Solved}

The handover of hospitals to the counties did not, in itself, cure many ills, although it did create a reasonably unified system of hospital organization out of a highly complex one and it eliminated the need for difficult and time consuming decision-making processes and negotiations between local and county participants on economic responsibilities and compensation schemes. ${ }^{39}$ However, several difficult problems which had been prominent for decades remained.

The fact that the county had assumed financial responsibility and direction for all hospitals in its area did not alleviate the tension between localism and coordination at the county level. The hospital map of Norway was, to a great extent, the result of local initiatives to meet local welfare needs. A key idea behind the transfer of ownership to the counties was to enable a high degree of coordination and specialization by subordinating a hospital structure based on localism to one based on county planning. Of course, the idea in itself did not remove differences of interest and conflicts between localism and

\footnotetext{
${ }^{34}$ Hansen, op. cit., note 9 , p. 48.

${ }^{35}$ Martinsen, op. cit., note 26 above, pp. 367, 371.

${ }^{36}$ Flo, op. cit., note 25 above, pp. 52-8.

${ }^{37}$ Ibid., pp. 38-43. Counties were not always enthusiastic about county ownership of hospitals, obviously fearing rising costs, see Johansen, op. cit., note 18 , pp. 218-24.
}

\footnotetext{
${ }^{38}$ Flo, op. cit., note 25 above, pp. 37-57; Grønlie, 'Velferdskommune og utjevningsstat', op. cit., note 7 above, pp. 199-281.

${ }^{39}$ Engesæter and Thue, op. cit., note 9 above, p. 278; Johansen, op. cit., note 18 above, pp. 218-24.
} 


\section{Norwegian General Hospitals, 1970-2002: County Ownership}

"county-ism", physically speaking between the central hospitals and the local ones, and between their communities of location.

The transfer to the counties did nothing to lessen the tension between a local and countybased organization and the increasing need to specialize on a regional basis above the county level. ${ }^{40}$ Moreover, assigning responsibility to the counties in no way addressed problems concerning national priorities and a national division of labour.

While the transfer removed problems concerning cost sharing between local and county interests, it did not remove tensions between county financial and budgetary responsibilities and the traditionally large contributions from the state (national health "insurance", investment support, contributions towards costs for out-of-county patients and specialized needs). The tension was there from the very beginning. It was, however, soon greatly increased by the fact that the birth of the new hospital organization occurred in the same decade when the strong economic growth of the post-Second World War period seriously slowed, and the first concerns arose over the nation's ability to pay for an increasingly generous welfare state.

There were also tensions between political priorities and direction on the one hand, and institutional hospital autonomy on the other. These were present at the county level, between county political and administrative authorities elected by popular vote on one side, and hospital administrative and professional leadership on the other. But these tensions also had a countrywide dimension, with national political priorities opposing the autonomy of the county. At times there were even conflicts directly between central political decision-makers and individual hospitals.

Competing strategies for the internal leadership of hospitals led to disagreements between the medical professions and the professional management (usually based on economic-administrative expertise), and even between different professions within the medical camp. Aina Schiøtz presents a concise description of the situation:

Lines of conflict have been drawn between the centre and the periphery, between national politicians and local ones, between experts and laymen, between different professions and between professionals locally and centrally. There have been conflicts on localization, on who is going to pay for what, on the meaning of "quality" and on who is the better qualified to lead and directdoctors or non doctors. ${ }^{41}$

All these tensions and conflicts had deep roots in Norwegian hospital history. ${ }^{42}$ An important point is that in taking over hospital ownership and management in the early 1970s, the county authorities were never able to start with a clean slate. Their success as

\footnotetext{
${ }^{40}$ Regionalization is, of course, a key issue in hospital politics in most countries, see, for example, Mohan, op. cit., note 2 above, pp. 45-67; and Daniel M Fox, Health policies, health politics: the British and American experience, 1911-1965, Princeton University Press, 1986.

${ }^{41}$ Schiøtz, op. cit., note 9 above, pp. $330-1$ (translated by Tore Grønlie): "Konfliktlinjene har gått mellom sentrum og periferi, mellom sentralpolitikere og lokalpolitikere, mellom fagekspertise og lekfolk, mellom profesjoner og mellom fageksperter lokalt og sentralt. De har dreiet seg om lokaliseringsspørsmål,
}

om hvem som skal betale for hva, om kvalitetsbegrepets innhold og om hvem som er best egnet til å styre sykehusene-leger eller ikke leger."

${ }^{42}$ The continual conflicts of Norwegian hospital history are stressed as well by Finn Henry Hansen, scholar of political science and an experienced toplevel health administrator, Hansen, op. cit., note 9 above, p. 36. In the case of Britain, Mohan shows how the 1962 Hospital Plan was envisaged to solve structural problems inherited from the pre-1948 system, but achieved only limited success, Mohan, op. cit., note 2 above, pp. 132-57. 


\section{Tore Grønlie}

hospital owners came to depend on their ability to solve problems that had accumulated over decades of uncoordinated hospital growth. There were many legacies of a hundred years of localism, others of lasting conflicts over the role and power of politics, and medical expertise and management in the organization and direction of hospitals.

To make matters even more difficult, the democratic enthusiasm that lay behind the creation of the new county authorities in the late 1960s and early 1970s soon faded. County authorities were not, as had been envisaged, empowered with new public functions, and almost from the beginning suffered from a lack of trust. Instead, new state bureaucracies were created at the county level. The county authorities headed for a long uphill fight for legitimacy with politicians and bureaucrats at the national level, and with their own voters at the county level. ${ }^{43}$

\section{County Ownership: The Struggle over Inherited Problems}

There is not much historical research on the organizational development of hospitals in the period of county ownership, but one main impression is that the counties expended a lot of energy trying to solve inherited problems - and that they did not succeed very well. This, in turn, was a major impetus behind the state takeover of 2002. Limitations of space allow for only a brief outline here.

Counties struggled with localism from the very beginning, and probably in most cases lost. The history of Norwegian hospitals testifies to the strength of localism. There were no easy agreements to be found on the merits of specialization or the removal of local hospitals that had been won by local initiative and resources. In several counties, the conflicts over localization and centralization led to bitter and lasting political—and professional—feuds. All parties to the conflict argued for the rights of patients; the centralizers lobbied for the best specialized care, the localists for the security of nearness. In some cases, localism was reinvigorated, rather than the opposite, by political compromises engineered to strengthen both specialization and localism at the same time. County authorities were more interested in an overall expansion of county hospital care, than in the specialization and restructuring of the system as a whole. At this stage of research it seems reasonable to argue that "hospital Norway" was witnessing a victory of localism over county-ism. Only a handful of local hospitals were eliminated or amalgamated with bigger units. ${ }^{44}$ At the same time, with rising costs and the technological revolution in hospital medicine, localism, on the county and national levels, tended to be considered more and more of a problem.

There was also a victory of county-ism over regionalism. A system consisting of a few regional hospitals (one for each landsdel), above the central hospitals of the counties, had been decided on shortly after the Second World War. A government White Paper of 1974 divided the country into five health-care regions. A working system of specialization and division of labour on a regional basis had to be created by cooperating counties. A regional health board was established to stimulate and coordinate county cooperation on a regional basis. But, of course, there were no easy solutions. Counties wanted highly specialized

\footnotetext{
${ }^{43}$ Flo, op. cit., note 25 above, pp. 68-113.

${ }^{44}$ Schiøtz, op. cit., note 9 above, p. 324 ,

374-79; Engesæter and Thue, op. cit., note 9 above,

pp. 217-24; Hansen, op. cit., note 9 above, p. 54 .
} 


\section{Norwegian General Hospitals, 1970-2002: County Ownership}

functions within their own territory. As long as cooperation was voluntary, not much was achieved. The health regions of the time have been labelled "little more than symbolic superstructures". ${ }^{45}$ In 1993 the state made the development of a regional health plan compulsory, and in 1999 regional cooperation — through the regional health boardswas made mandatory by law. The new system undoubtedly laid the grounds for a more authoritative approach towards regionalization. The structure lasted, however, only a short time before state takeover. ${ }^{46}$

Financial problems grew. The promises of a rise in state contributions to the hospitals' operational costs- to 85 per cent-were never kept. On the contrary, basic state contributions to hospital budgets decreased considerably-in 1977 down to 50 per cent. Between 1970 and 1980 running costs of Norwegian hospitals grew by a stunning average of 14 per cent a year. The annual growth was down to a meagre 1 to 1.5 per cent during the 1980 s and first half of the 1990s, then again up to more than 5 per cent in the second half of the 1990 s. $^{47}$ The haggling between the state and counties over who was supposed to pay for increasing costs intensified. The funding system was repeatedly changed or modified to make hospitals more cost-efficient, without any lessening of conflicts. ${ }^{48}$ Conflicts made for the continuing playing of strategic games - to make the other side pay. For counties that hosted regional hospitals, the fact that the state paid all expenses for the National Hospital (Rikshospitalet) in Oslo was a constant thorn in their side.

Continuing conflicts over resources intensified the debate over autonomy versus political control. Hospitals wanted autonomy from county authorities, while at the same time building alliances to increase budgets. County authorities wanted autonomy from the state, while at the same time lobbying for increased state funding. Decisions at lower levels tended to be appealed to higher levels. On occasion, hospital leaders and local representatives could not refrain from bypassing the county level. The national assembly (Stortinget), tended to become the highest court of appeal when regional interests or popular issues were at stake. Conflicts and conflicting ideologies concerning internal leadership continued to plague the system, at times more intensely than ever. ${ }^{49}$

Given the limited scope of this presentation, I have to leave it at this general level. ${ }^{50}$ Hopefully, the main point is clear. Most of the problems facing county authorities as hospital owners were already there when they took over. And, even though they worked

\footnotetext{
${ }^{45}$ Hansen, op. cit., note 9 above, p. 54: "lite mer enn symbolske overbygninger". Tore Grønlie's translation.

${ }^{46}$ Ståle Opedal and Inger Marie Stigen (eds), Evaluering av regionalt helsesarbeid: sluttrapport, NIBR-rapport 2002:22, Oslo, NIBR, 2002; Schiøtz, op. cit., note 9 above, pp. 328-9.

${ }^{47} \mathrm{O}$ V Slåttebrekk and H P Aarseth, 'Aspects of Norwegian hospital reforms', Eurohealth, 2003, 9 (2): $14-16$.

${ }^{48}$ Schiøtz, op. cit., note 9 above, pp. 379-80; Maren Skaset, 'Reformtid og markedsgløtt: Det offentlige helsevesen etter 1985', in Schiøtz, op. cit., note 9 above, pp. 499-548, on pp. 505-7. A system of block grants from the state was introduced in 1980 after years of debate. From 1997, 30 per cent of block grants, rising
}

to 60 per cent in 2003, was made dependent on hospital activity. There still is no thorough historical analysis of the development of the system of hospital financing in Norway.

${ }^{49}$ Schiøtz, op. cit., note 9 above, pp. 382-3; Skaset, op. cit., note 48 above, pp. 506-7.

${ }^{50}$ The present article focuses on basic and persistent conflicts and tensions concerning political and administrative direction and management of hospitals. A complete analysis of the successes and failures of the county authorities as hospital owners would have to include indicators more directly pertinent to patient care, such as waiting lists, access, questions of equality across counties and regions, etc. In Norway, historical research on this side of county hospital performance is still in its infancy. 


\section{Tore Grфnlie}

hard, these were not solved. That is not to say that the county authorities did a bad job in hospital direction. They did what could be expected given the cards they were dealt and the limits of what was politically possible in the system created around 1970 . They probably even solved a number of problems. But they did not manage to solve the basic conflicts and tensions that had been built into the hospital system over a hundred years. Expecting them to do so was, no doubt, unrealistic.

\section{State Takeover in 2002: Why and How?}

"The winter of our discontent", is a reasonable way of characterizing the greater part of thirty years of county hospital history. County authorities had to submit to being the scapegoat for nearly everything that went wrong in the hospital sector, regardless of whether the problems originated in county decision-making and/or were within the counties' control. Nevertheless, for years virtually everyone continued to search for solutions within the framework of county ownership. It could also be argued that county authorities in later years had somewhat greater success in counteracting localism, and at the same time lent greater support to regional cooperation, than during the first decades of county hospital rule. ${ }^{51}$ Then, shortly after the turn of the century, almost overnight, state takeover won the day. And the process leading up to the change made it appear the only possible solution a short time after very few had wanted it. How did this happen?

There is still not much detailed historical research on the fine political mechanics of state takeover. The solid parliamentary majority that voted in favour of the reform consisted of the governing (in minority position) Social Democrats, supported by the Conservatives and the Progressive (populist right) party. The Radical Left and Centrists (Christian Democrats), Liberals and the Centre (Agrarians) were opposed. These parties were in general strongly in favour of local and county self-government. Conservatives and Progressives, on the other hand, had for some time opposed the continuance of the county level of governance. ${ }^{52}$ Research on the parliamentary stage of the process will have to focus on the changing position within the governing Labour Party and on the political leadership that made it possible. One such study emphasizes the strong and determined leadership of the newly appointed Minister of Health, Tore Tønne, the Prime Minister, Jens Stoltenberg, and other leading figures of the governing Labour Party and a top-down, heavily centralized, and unusually speedy process of decision made with no extensive process of deliberation or scrutiny of effects or consequences. ${ }^{53}$

The analysis here, however, will be one mainly of structures and trends. The focus will be on the combined effects of four strong, relatively long-term development trends, each by itself of prime importance, and one basic ideological shift. All of these worked

\footnotetext{
${ }^{51}$ F H Hansen, 'Sykehusstruktur: fortid-nåtidframtid?', in Hansen (ed.), op. cit., note 9 above, pp. 185-6; Opedal and Stigen, op. cit., note 46 above, pp. $5-12$.

${ }^{52}$ See parliamentary documents (Norway): Ot.prp., nr. 60 (2000-2001); Innst. O., nr. 118 (2000-2001); O. tid. (2000-2001),
}

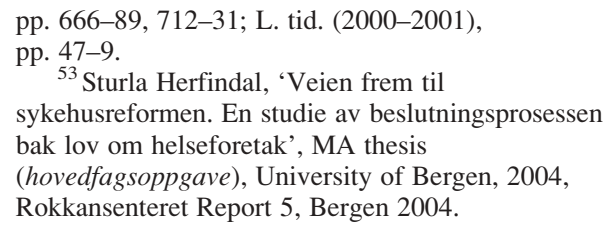




\section{Norwegian General Hospitals, 1970-2002: County Ownership}

together, making a winning coalition for state takeover not only a possible but a natural solution.

The first trend is for the country to be divided into new politico-adminstrative units or regions, which would embrace the counties. The desire for regionalization in hospital organization, and the processes aimed at achieving a regionalized pattern of specialization and division of labour have already been noted. Processes spanning thirty years or more had created a regionalized structure, and considerable effort had been put into making this structure work. To some, highly varying, degree it did. The main problem was that while regional cooperation in itself was mandatory, there was no authority above the counties that was empowered to make binding decisions. But the framework was there to serve as the foundation for a new state structure. Also important is the fact that the movement towards regionalization is a general one. Though no national decision to regionalize has been made, regionalization is increasing, incrementally and ad hoc, through decisions in a number of important societal sectors. In a few years, customs, taxes, police, and road construction and administration have been reorganized according to (different) regional principles. ${ }^{54}$ The trend could be seen as a return to the regional planning of the 1960s and 1970s. At that time, the region lost out to the county because it lacked democratic legitimacy. ${ }^{55}$ Today, it is reasonably clear that the process of regionalization contributes greatly towards breaking down the county as the basic geographical unit of mid-level government organization. There is good reason to believe that this strongly affects both the popular elected county authorities and state functions at the county level.

The second process is one of de-democratization at the local, county and regional levels. In the early 1970s, placing financial responsibilities and the power of priority over important welfare sectors in the hands of county political authorities, elected by popular vote, was one of the strongest credos of its time. In the new regionalized hospital organization, there is no element of mid-level democratic influence at all, at either county or regional level. The region has no common governing institutions, only state sector bureaucracies. The government, in its proposition to Parliament, stated that no practising politician ought to sit on any board of any of the new hospital enterprises, and this principle was followed when the boards were later appointed. A feeble, seemingly tactical suggestion, involving some kind of politically composed, regional advisory board, was defeated. This "keep-thecounty-politicians-out" axiom, was a clear reflection of the growing distrust of the role of county politicians in hospital matters. ${ }^{56}$ Hospitals and their professionals disliked county politicians for interfering in professional affairs and for keeping the lid too tight on the coffer. Central politicians tended to take the opposite view. Counties spent money at the expense of the state, while at the same time they did not manage to direct and coordinate hospitals so as to reduce costs and eliminate waiting lists. During the years of county rule, the conflict over the role of politicians in hospital affairs was often played out precisely

\footnotetext{
${ }^{54}$ Harald Baldersheim, 'Det regionpolitiske regimet i omforming - retrett frå periferien; landsdelen i sikte!', Norsk Statsvitenskapelig Tidsskrift, 2003, 3: 276-307; Harald Baldersheim and Larry E Rose, 'Kampen om kommunen: Foran et nytt kommunalt hamskifte', Norsk Statsvitenskapelig Tidsskrift, 2003, 3: 231-9.
}

\footnotetext{
${ }^{55}$ Flo, op. cit., note 25 above, pp. 43-9.

${ }^{56}$ See parliamentary documents, note 52 above. The negative attitude towards democratic input is central to recent British hospital reform as well, see Mohan, op. cit., note 2 above, p. 220
} 


\section{Tore Grønlie}

over the question of the composition of hospital boards; should politicians representing county authorities be in a majority position on the boards? Should they be on the boards at all? ${ }^{57}$

The de-democratization of the county and local levels is-like regionalization-a general trend. As already noted, the democratically elected county lost the trust of central politicians and bureaucrats almost from the beginning, while state bureaucracies at county level grew. There are clear parallels on the local level of self-government. Parliamentary decisions with a high degree of detail, followed by financial schemes specifying precisely how the money granted is to be used, have dramatically reduced leeway in local democratic decision-making. This is aggravated by the strong tendency towards legislation and welfare schemes that grant individual rights. Turning welfare benefits into legal rights makes them the jurisdiction of the courts, rather than matters for democratically elected decisionmakers. ${ }^{58}$ In the 2003 final report from the research programme 'On Democracy and the Distribution of Power in Norway', it is argued that de-democratization of the local and county levels is one of the country's more serious political problems. ${ }^{59}$ The public generally seems to be a lot more concerned about the level and quality of public service than about democratic participation. It also seems reasonable to draw a parallel with the strong tendency towards de-democratization represented by the transformation of state owned public utilities and infrastructure into companies and autonomous state enterprises, thus removing them from the hands of politicians.

The third tendency is closely linked to the second: the expansion of state functions at the expense of local and regional organization (statliggj申ring). It is worth remembering that the state has always been a most active partner in Norwegian hospital organization and direction, as determiner of national health policy, hospital investor, major contributor towards running expenses, creator of the hierarchy of regional and county hospital specialization, final guarantor of health quality control, and owner of the Rikshospitalet with highly specialized functions. There is no doubt that the involvement and influence of the state continued to grow throughout the county period of hospital organization, at a time when leading state actors had no plans whatsoever for state takeover.

Nevertheless, in a long historical perspective, state takeover of hospitals could be seen as another, though especially important, element in the general development from welfare localism to a real welfare state, with the emphasis on state. Welfare sectors, almost as a rule, have a long tradition of localism in Norway, before they became supported, heavily regulated and then gradually taken over by the state. Some of the more important sectors may serve as examples: labour market organization, the police, the tax regime, and the

\footnotetext{
${ }^{57}$ After two years of mounting criticism about the lack of democratic influence over the regional hospital boards, the coalition government of the Labour Party, the Agrarian Party and the Socialist Left, which came to power after the 2005 elections, has promised to reinstate county politicians on the boards.

${ }^{58}$ Baldersheim and Rose, op. cit., note 54 above, pp. 231-9; Anne Lise Fimreite, Der hvor intet er, har selv keiseren tapt sin rett! Om lokalt folkestyre
}

og rettigheter, Rokkansenteret Report 8, Bergen, 2003; Anne Lise Fimreite and Yngve Flo, 'Den besværlige lokalpolitikken', Nytt norsk tidsskrift, 2002, 3: 310-21.

${ }^{59}$ Øyvind Østerud, Fredrik Engelstad and Per Selle, Makten og demokratiet: en sluttbok fra Makt-og demokratiutredningen, Makt- og demokratiutredningen 1998-2003, Oslo, Gyldendal, 2003, pp. 9-151. 


\section{Norwegian General Hospitals, 1970-2002: County Ownership}

highly varied system of peoples' pensions schemes. ${ }^{60}$ And, just to underline the current expansion of the state, shortly after hospitals were taken over by the state, the same thing happened to child welfare services and institutions for the treatment of alcoholics. Social benefits are still part of the domain of local authorities, but a reform coordinating social benefits, unemployment authorities, and the health insurance and pensions is now taking effect under state leadership. From this perspective, the hospital sector is only one of many in the latest wave of welfare provisions and institutions taken over by the state in the name of equalizing welfare nationally.

The trend in recent decades towards "more state in the welfare state", however, now seems to be caused by a greater ambition for national welfare equality than ever before. The state's desire to ease and level welfare differences between different regions and parts of the country (utjevningsstaten - the leveller state) has gradually been replaced by a quest for total equality and individual welfare rights. ${ }^{61}$ A lack of equality on local or county grounds due to different priorities and varying ability to pay no longer seems to be acceptable. Leading politicians at the national level are continually confronted by media-raised pressures, often grounded in national statistics documenting geographically or socially based inequalities. Proclamations concerning "unacceptable differences" caused by local or county authorities create pressure for more state involvement. At a time when in many countries decentralization is gaining strength as a strategy for keeping public costs down, this has not, so far, been the case in Norway. The revenues from North Sea oil have made it possible to continue development of costly welfare services, and an increasingly ambitious equalization policy, with state authorities in the lead.

The fourth trend-and the only one directly connected to the organizational form chosen-is towards organizing public functions in institutions that are autonomous or semi-autonomous in relation to political or administrative public authorities. This is, of course, a highly international trend, linked to the breakthrough of New Liberalism and New Public Management in the 1980s. This reform thrust prescribes a thorough modernization of the public sector, privatization, and a wide range of principles of management, competition and organizational models from the private sector. The more radical contents of New Public Management, especially privatization, never gained a strong foothold in Norway, and in the 1980s and 1990s the country was generally a hesitant reformer compared with the front-runners in New Public Management, such as, for example, New Zealand. ${ }^{62}$ Typically, a report from the early 1990s by a committee headed by the junior minister of the Ministry of Social Affairs suggesting a trial organization of hospitals as limited liability companies received little support, and seems to have been put aside immediately. The solution obviously had too much of a private flavour to it.

\footnotetext{
${ }^{60}$ Grønlie, 'Velferdskommunen, op. cit., note 7 above, pp. 43-52; Hovland, op. cit., note 7 above, pp. $127-43$.

${ }^{61}$ Fimreite, op. cit., note 58 above; Fimreite and Flo, op. cit., note 58 above.

${ }^{62}$ Christopher Pollitt and Geert Bouckaert, Public management reform: a comparative analysis, Oxford University Press, 2000; Tom Christensen and Per Lægreid (eds), New public management: the
}

transformation of ideas and practice, Aldershot and Burlington, VT, Ashgate, 2001; Bengt Jacobsson, Per Lægreid and Ove K Pedersen, 'Robust and flexible states: the transnationalisation of Nordic central administration', Zeitschrift für Staats- und Europawissenschaften, 2004, 1: 1-24; Tom Christensen and Per Lægreid, 'New Public Management i norsk statsforvaltning', in Tranøy and Østerud (eds), op. cit., note 1 above, pp. 67-95. 


\section{Tore Grønlie}

Nevertheless, the tendency to organize public functions in autonomous or semiautonomous positions relative to political or administrative authorities was strong in Norway and, in fact, had five decades of forerunners, especially in the field of industrial policy and development. These experiences, as it turned out, were not irrelevant for the hospital field. Two developments of the 1990s seem to have had, over time, a strong bearing on the choice of a new model for the organization and direction of hospitals. The first, from the early and mid-1990s, was a powerful stratagem to move public service functions away from organizational forms within or near public administration and to give them greater independence. This was in line with international developments, in this Norway was greatly inspired by the EU. The telephone and postal services, power production and supply, and the railways were among those affected. The second development, however, was more of a Norwegian invention, a general tendency to search for compromise organizational forms, such as moving public functions out of the direct line of command from politicians and public administrations, with the minister of the relevant sector still retaining statutory rights to give (formal) political instructions. In a Scandinavian comparative perspective, we might be witnessing the emergence of a Norwegian model for organizing public utilities, infrastructures and services. ${ }^{63}$

The model originated after the establishment of the national oil company, Statoil, in the 1970s. The company was organized as a limited liability company, but its statutes included a paragraph requiring the Minister of Oil and Energy to be consulted before decisions of prime societal importance were taken. The telephone company, renamed Telenor, was organized in accordance with the same model in 1994. During the 1990s, the Norwegian authorities, in general, showed considerable creativity, constructing several middle-of-theroad solutions for a number of public functions, organizing them as enterprises (foretak) independent of bureaucracy, while retaining some political control. Statutory provisions of the Statoil/Telenor type flourished. ${ }^{64}$ There is every reason to believe that the legislation of 2002, organizing Norwegian hospitals as state regional enterprises, was strongly inspired by this development. Central players in the process had earlier been involved in transformations in the industrial and public utilities field. The newly appointed Minister of Health, Tore Tønne, who personally promoted the reform, had experience as the head of the Agency for Industrial and District Development, which had a similar organizational form, and in private business as well. The main difference between the statutory provisions that politically empowered the Minister in the cases of the regional health enterprises and Statoil/Telenor was their degree of detail: the key section of the statutes of the Regional Health Enterprises gives a detailed list of important decisions that are to be referred to the Minister, as the ultimate authority of the enterprise assembly. ${ }^{65}$ In addition to this, it was explicitly stated that state grants for the regional enterprises could be made dependent on

\footnotetext{
${ }^{63}$ Grønlie, 'Mellom politikk og marked', op. cit., note 1 above, pp. 301-32; Øyvind N Grøndahl and Tore Grønlie, 'From the Swedish ideal to EU direction: Scandinavian central state administrative reform in the 1980s and 1990s, in a post-1945 perspective', Jahrbuch für Europäische Verwaltungsgeschichte, 2004, 16: $151-96$.
} 


\section{Norwegian General Hospitals, 1970-2002: County Ownership}

conditions set by the Minister and his Department of Health without a formal decision by the enterprise assembly.

The main point here is that in the course of the 1990s a realistic state organizational alternative to the reigning county ownership gradually appeared for the very first time. This did not mean, of course, an immediate and collective adoption of this solution. Most reports and statements throughout the 1990s argued for carrying on county ownership while, at the same time, giving hospitals greater independence within this organizational form. A provision in the new law on local self-government of 1992 for creating municipal and county enterprises probably catered to this need. The years approaching the millennium, however, turned out to be somewhat of a melting pot for organizational ideas, resulting in several radical reforms and developments. This leads finally to ideology and political leadership.

There was an ideological shift in Norway, as in many parts of the western world, in the early and mid-1980s. There was obviously a move towards liberalism, a strengthening of the new right, a thrust towards the reform of the public sector and bureaucracy, and a turn towards the market, competition and management. This change primarily affected the parties of the right, but can also be traced in Social Democracy, heavily burdened by the realization of the breakdown of comprehensive planning and the Keynesian countercyclical policies of the late 1970s. This change triggered comprehensive debates on reorganization, including that of the hospital sector. In general, however, changes during the 1980s consisted more of rhetoric and the politics of symbolism than of substantial reforms. ${ }^{66}$ The hospital sector was even more resistant than most.

In Norway, the second ideological shift, from the mid-1990s, was far more substantial, and this time it cut deep into Social Democracy as well. While the 1980s were still characterized by thoughts of "planning" and "direction", "market" and "competition" were the order of the day in the 1990s. This is clearly seen in industrial policy, the general process of autonomization and devolution, privatization and the stock exchange listing of major state-owned companies. It is reflected in a decreasing support for decisions through democratic processes and increasing support for independent and authoritative processes of professional leadership. Public administration and bureaucracy were scrutinized in an intensified hunt for unnecessary functions, dual administrations and work done twice or more. In this process, county authorities were viewed more negatively than other tiers of government. Did Norway really need both self-governing authorities and state functions at the county level? Did Norway need a level of government between the local authorities and the state at all? The trust in county authorities elected by popular vote fell, probably to an all-time low.

\section{Concluding Remarks}

The ideological change among the leaders of the Labour Party, therefore, became the decisive factor behind the transformation of hospital organization. This change made possible the creation of a winning coalition of state enterprise. It appears that a compromise was found, transforming the field of hospital organization and direction, which

\footnotetext{
${ }^{66}$ Grøndahl and Grønlie, op. cit., note 63 above, pp. $168-83$.
} 


\section{Tore Grфnlie}

commanded a hefty 50 to 75 per cent of the county authority budgets, while at the same time allowing the self-governing county authorities to limp on-for the time being.

The main argument of this paper, however, has been, that county authority ownership, in a long-term perspective, could be seen as an uneasy interlude in a century-long quest for a way to solve the permanent tensions and conflicts in Norwegian hospital organization, the most important being the contention between localism and state direction. County authority organization was the preferred structure in the early 1970s, in hospital direction as in government reform in general, but, as it turned out, this soon lost popularity. The interlude lasted thirty years, at least partly because no good alternative was found. It ended because the quest for national equalization by the state became steadily more compelling, and because a realistic alternative was finally found, which this time also coincided with the dominant organizing principles of the day. County organization, a strong belief in localand mid-level democratic processes and anti-bureaucratic sentiment ruled the land in the early 1970s. The hegemonic government reform paradigm of today relies heavily on regional reorganization, semi-autonomous enterprises under professional or bureaucratic leadership and central state direction of welfare. How to organize seems more important than what to organize.

From a historical perspective there was, at the time of reorganization, little reason to believe that state takeover would remove a century of conflicts and tensions in hospital direction overnight. The state inherited in 2002 much the same problems as the county authorities had some thirty years earlier, and, as was to be expected, problems traditionally inherent in the semi-independent state enterprise model would also be taken on. ${ }^{67}$ Four years have passed since state takeover, and it is far too early to evaluate historically the merits of the new system. It is, however, no big surprise, that during those four years, the regional enterprise system has been plagued by a host of problems. Nor is it surprising that among the most important of these problems are localism versus county-ism and regionalism, serious conflicts between regional enterprises and the state over financial obligations and bigger-than-ever deficits, conflicts over enterprise and local hospital autonomy, the role and functions of the Minister of Health and his bureaucracy in enterprise decisionmaking, and the problems in defining the role of politicians. This time, however, these are not county-level politicians, but the Minister and Members of Parliament—in far-away Oslo. ${ }^{68}$

\footnotetext{
${ }^{67}$ See Grønlie, 'Mellom politikk og marked', op. cit., note 1 above, pp. 301-32.

${ }^{68}$ It now seems possible to draw some preliminary conclusions from the ongoing social science research on the four years of putting the reform into effect. The reform, hailed by proponents as an instrument of decentralization, so far, displays clear signs of centralization. Regional enterprises have been subjected to detailed instruction from highly active Ministers of Health, both through the use of extraordinary "enterprise assemblies" and through departmental politico-administrative instruction. Paralleling this, Parliament and individual members of Parliament have been more active in hospital affairs than before state take-over, often delving into conflicts concerning the balance between localism and
}

centralization, thus in many ways filling the vacuum left by the elimination of county politicians from hospital politics and organization. See, for example, Lægreid, Opedal and Stigen, op. cit., note 1 above; Christensen, Lægreid and Stigen, op. cit., note 1 above; Ståle Opedal and Hilmar Rommetvedt, 'Foretaksfrihet eller stortingsstyring?', in Opedal and Stigen (eds), op. cit., note 3 above, pp. 64-85; Ståle Opedal, 'Helsedepartementets styring av helseforetakene rollemangfold og styringsutfordringer', in Opedal and Stigen (eds), op. cit., note 3 above, pp. 86-106; Haldor Byrkjeflot and Tore Grønlie, 'Det regionale helseforetaket - mellom velferdslokalisme og sentralstatlig styring', in Opedal and Stigen (eds), op. cit., note 3 above, pp. 198-218. 